\title{
Tropes of (mis)understanding: imagining shared destinies in New Caledonia, 1853-1998
}

\section{Adrian Muckle}

\section{(2) OpenEdition \\ 1 Journals}

\section{Electronic version}

URL: http://journals.openedition.org/jso/819

DOI: $10.4000 /$ jso.819

ISSN: $1760-7256$

\section{Publisher}

Société des océanistes

\section{Printed version}

Date of publication: 1 June 2007

Number of pages: 105-118

ISBN: 978-2-85430-010-9

ISSN: 0300-953x

\section{Electronic reference}

Adrian Muckle, "Tropes of (mis)understanding: imagining shared destinies in New Caledonia, 1853-1998 », Journal de la Société des Océanistes [Online], 124 | Année 2007-1, Online since 01 June 2010, connection on 22 April 2019. URL : http://journals.openedition.org/jso/819; DOI : 10.4000/ jso.819

\section{(c) Tous droits réservés}




\section{Tropes of (mis)understanding: imagining shared destinies in New Caledonia, 1853-1998}

par

Adrian MUCKLE*

\begin{abstract}
The paper critically assesses the preamble to the 1998 Nouméa Accord by reading it against a longer history of official and unofficial attempts to imagine or define relationships between Kanaks, settlers and the French State. Particular attention is paid to the way in which the destinies of the different ethnic groups have been imagined following periods of conflict and the way that tropes of misunderstanding or incomprehension have been used to account for such conflicts.
\end{abstract}

Keywords: New Caledonia, Noumea Accord, colonial history, conflict, Kanak identity, misunderstanding

In 1981, historian Jean Chesneaux asked «Can two opposite views of the past be turned into one in the future?». In New Caledonia, Kanaks (the indigenous Melanesian inhabitants) and Caldoches (New Caledonian-born people of French extraction) possessed separate traditions, memories and senses of the past. For Kanaks, the period since 1853 had been «a long night» of dispossession suffered in silence. For Caldoches, there was the «taboo» of the colony's penal heritage. Noting the Caldoche enthusiasm for «Anything judged likely to enhance the

\section{RÉSUMÉ}

Cet article amorce une réflexion critique sur le préambule de l'accord de Nouméa en lisant ce dernier texte par rapport à une histoire plus longue de tentatives officielles et non-officielles pour imaginer ou définir les rapports entre les Kanaks, les colons et l'État français. Nous examinerons comment les destins des divers groupes ethniques ont été envisagés après les périodes de conflit et nous remarquerons l'accent mis sur les tropes de la mésentente ou de l'incompréhension dans l'explication de ces mêmes conflits.

Mots-CLÉS : Nouvelle-Calédonie, accord de Nouméa, histoire coloniale, identité kanak, incompréhension

historical image of the white presence» (the culture of the stockman and the deportation of members of the Paris Commune), Chesneaux wondered how many of them would be «prepared to make a drastic reappraisal of the [then] 128 years of white power?» He suggested that it would «no doubt be at this price that they may remain in this New Caledonian land which is, after all, "their country" too» (Chesneaux, 1981).

Chesneaux was neither the first nor the last person to reflect on historical consciousness in

* History Programme, Victoria University of Wellington, New Zealand, adrian.muckle@vuw.ac.nz 
New Caledonia. In the early 1960s, a Kanak Catholic priest, Apollinaire Anova-Ataba, had written the first Kanak history of the 1878 war in which as many as 200 settlers and 1000 Kanaks had lost their lives. Ataba identified Kanak shame and European silence surrounding this war as a barrier to future development and urged that it be addressed (Anova-Ataba, 1969: 202) ${ }^{1}$. In 1992, a New Caledonian historian, politician and schoolteacher of convict descent, LouisJosé Barbançon, publicly reflected on the possibility of invoking a shared past. He identified the principal barrier as the non-dit (the unspoken): the idea that the descendants of convicts and the descendants of Kanaks who had fought on opposing sides in colonial conflicts such as the 1878 war ought to confront their pasts more openly. Barbançon, like Ataba, suggested that a potential site for a discourse of shared history was to be found in histories of Kanak and settler resistance to Metropolitan authority (Barbançon, 1992: 22-23) ${ }^{2}$.

These appraisals are part of an ongoing critical reflection on the ways in which New Caledonia's past is represented in public discourse and historical consciousness. There have been other interventions on this theme in the form of historiographical studies (Aldrich, 1989; Angleviel, 2002), analyses of political, media, literary and museum representations (Jouve, 1997; Chanter, 1999 and 2002; Veracini and Muckle, 2002) and political commentary on reconciliation initiatives (Macllelan, 2005). Earlier appraisals have drawn attention to silences and absences and the need to recognise and come to terms with processes of colonisation and the violent conflicts associated with this, notably the 1878 war which was the largest conflict of its kind in New Caledonia. For Anova-Ataba addressing this silence was a precondition for development. For Barbançon it was necessary to become Caldoche before becoming Caledonian. More recently, there have been warnings that the surge of interest in the past may lead to «new falsifications» (Terrier-Douyère, 1994: 208) or even an attempt to create a «New CaledoFrance» (Boengkih, 1994). In 1996, Jacqueline Dahlem observed that the new history manual produced in the wake of the Matignon Accords represented an illusion of unity, in that it took the form of «one account», but was in fact composed of «two histories»:

"Two opposed and complementary visions of the "same country" and "its history".» (Dahlem, 1996: 125)

Since its signing in 1998 the preamble to the Nouméa Accord has come to occupy a central place in writing about Kanak-settler relations, reconciliation and the political future of New Caledonia. This political agreement, signed by the French State and representatives of New Caledonia's principal pro- and anti-independence parties, continues the rebalancing project of the 1988 Matignon Accords by laying out the increasingly autonomous future of New Caledonia until $2018^{3}$. From almost the moment the Accord was signed, the preamble was hailed for its unprecedented acknowledgement by the French State and by the non-Kanak signatories of a Kanak identity and of the effects of French colonisation (Naepels, 1999; Chappell, 1999: 385-386). Within New Caledonia, the Noumea Accord has been widely accepted as a challenge, a goal that people must work together to realise, notwithstanding the assertion by the League of Human Rights that the preamble has remained a «dead letter» (Ligue des droits de l'homme de Nouvelle-Calédonie, 2003) ${ }^{4}$.

Not surprisingly given its symbolic and constitutional importance, there has been little commentary on what this public document has to say about New Caledonia's colonial past and the implications that it has for the community- or country-building project that it foreshadows. With particular reference to the potential that past moments of contact and conflict have as sites for the foundation of postcolonial futures, this article critically assesses the preamble to the Noumea Accord by reading it against a longer history of official and unofficial attempts to imagine or define relationships between Kanak, settlers and France. Bearing in mind that the preamble's purpose is to clear the way for a new relationship between Kanak, non-Kanak settlers and the French state and a process of deco-

1. Anova-Ataba was amongst the first generation of Kanak to be admitted to the Catholic priesthood and one of the first Kanak to study in France. "The Insurrection of New Caledonians in 1878 and the Personality of the Great Chief Ataii» (published in 1969) was the preface to a thesis in economics and sociology prepared in Paris between 1963 and 1965 and which was eventually published in 1984.

2. Unless indicated otherwise, all translations from the French are my own.

3. The Noumea Accord was signed by representatives of the French State, the Kanak Socialist National Liberation Front (FLNKS) and the Rally for New Caledonia in the Republic (RPCR).

4. The League recognises the «historic, philosophical and political» significance of the preamble and in particular makes the point that for the first time the "History of the "Country"» has been presented from the perspective of both «the colonisers» and «the colonised». 
lonisation $^{5}$, I discuss the ways in which dispossession, colonisation, conflict and different categories of immigrants are represented in its overview of New Caledonia's history and consider the extent to which this constitutes a departure from earlier representations of relations between settlers, administrators and Kanaks.

\section{Dispossession or conquest: legitimising the colo- nial presence}

In the first of its five sections, the preamble to the Noumea Accord claims that France appropriated New Caledonia in 1853 «in accordance with the conditions of international law, as recognised at that time by the nations of Europe and America». The signatories recognise, however, that France «did not establish legally formalised relations with the indigenous population», that this territory was not «empty» and that the land was occupied by Kanaks who had their own identity, civilisation, languages and culture. In the third section it is noted that, through a «process of dispossession», Kanaks lost their land, resources and identity markers (Noumea Accord, 1998). An insistence upon the legitimacy of the act of possession in international legal terms is finely balanced with the recognition (and implied moral condemnation) of the consequences of this unilateral action. The assertion that dispossession was legal under the international law of the time already has been challenged by at least one scholar (Berman, 2001); what I argue here is that this dual recognition of the acts of possession and dispossession forms part of the historical denial of the legitimacy of Kanak resistance to colonisation.

After claiming New Caledonia in 1853, and a succession of wars with Kanaks in the 1850s and 1860 s, French settlers and administrators began to lay the foundations of colonial development. As early as the mid-1860s, guides for settlers had promised that «Since we took possession of the island our settlers have not been disturbed by any serious uprising and today our influence is sufficiently well established that we can find numerous auxiliaries amongst the natives converted to christianity» ([Anon.], 1864: 15). As penal settlement, cattle grazing and mining took hold in the 1870s administrators became less concerned with Kanaks and assumed that they would eventually disappear (Faure-Biquet, 1876).

It was partly because of such assumptions that the outbreak of a war involving different groups of Kanaks, settlers and the French military, and the loss of more than 200 settler lives, including that of the French Colonel GallyPasseboc, came as a tremendous shock for settlers in 1878-1879. The administration relied heavily upon Kanak auxiliaries to contain the conflict and participate in the repression which ended with the deaths of more than 1000 Kanaks, including the chief Ataï, mass deportation and the confiscation of land. The gravity of the threat to the French presence and the process of colonisation required serious consideration of both the causes of the conflict and the place of Kanaks and settlers in the colony. Contrary to earlier claims, the presence of Kanaks could not be ignored, nor could their participation in the future development of the colony be taken for granted.

In 1879 , the commission set up under General Arthur Trentinian to report on the causes of the «insurrection» argued that there had never been a conquest because Kanaks had previously accepted French domination and because France's intent had been to avoid genocidal conflict:

«[I]n coming here we renounced the idea of imitating the ENGLISH in TASMANIA [...]; moved by a generous sentiment, while taking possession of the land, we wanted to reserve rights to Canaques, to live in good harmony with them. But colonisation took off, the first promises were forgotten and no one imagined that there would necessarily be a fight with those from whom we took the Territory without having conquered it.» (Nouvelle Calédonie et Dépendances, [1879])

The commission claimed a moral high ground, referring to the British treatment of Aborigines in Tasmania, to insist upon an originally benign French intent with regard to Kanaks that had been corrupted or compromised by the process of colonisation ${ }^{6}$.

Advocates for further colonisation and settlement nevertheless understood the 1878 war in

5. Section Three of the preamble states that: «Colonisation harmed the dignity of the Kanak people and deprived it of its identity. In this confrontation, some men and women lost their lives or their reasons for living. Much suffering resulted from it. These difficult times need to be remembered, the mistakes recognised and the Kanak people's confiscated identity restored, which equates in its mind with a recognition of its sovereignty, prior to the forging of a new sovereignty, shared in a common destiny» (Noumea Accord, 1998). In Section Four, decolonisation is described as «the way to rebuild a lasting social bond between the communities living in New Caledonia today, by enabling the Kanak people to establish new relations with France, reflecting the realities of our time» (Noumea Accord, 1998).

6. In more recent times, the RPCR leader, Jacques Lafleur, has made the following comment, citing a remark made by François Mitterand during a visit to New Caledonia in the 1980s: "'Obviously, he said with reference to the Australians, they don't have 
terms of racial and colonial conquest and the resistance that such a process was likely to engender. That «the natives are black and that we are white, that they are the first occupants of the country and that we are moving into their place» was the principal cause, according to one analysis; the delimitation of Kanak lands, forced labour and the violation of burial sites were dismissed as being of no consequence since it was «the French occupation» or «the antagonism of races» that had made «insurrection» inevitable (Anon. 1882: 118-125). The best known participant history of the war, Souvenirs de la Nouvelle-Calédonie - l'insurrection canaque - 1878, by naval officer Henri Rivière, rejected the legitimate causes of discontent as «a few isolated arbitrary acts or bad treatment». Instead, Rivière argued that the only genuine cause was «the antagonism that has always existed between the conquerors and the conquered» and the «savage» nature of Kanaks (Rivière, 1881: 131-132). Twenty years later, another advocate of further settlement saw the years following 1878 as «the period of Conquest» and the rapid extinction of Kanaks and argued that the land spoliations carried out before and after 1878 amounted to a «perfectly justified confiscation» (Archembault, 1904: 2 and 21-26).

Implicit in these assumptions of European racial superiority and Kanak inferiority as explanatory categories for the 1878 war were notions of progress and civilisation. It was with reference to these that Europeans absolved themselves of responsibility for conflict with Kanaks. After the war of 1917-1918, Governor Jules Repiquet, citing an earlier account of 1878 , told the Conseil général that no single person was responsible for the conflict:

«[I] have discovered, in a history of the 1878 insurrection, a most interesting article[...]: " [...]The actual reason for the insurrection is the French occupation, and New Caledonia cannot pretend to escape a fatal law suffered by all colonies in which the civilising element has found itself battling against the barbarian element it invaded. [...]Thus, the real cause of the insurrection is the antagonism of races: given the presence of blacks and whites, of civilised people and savages, a war of extermination was inevitable from the day that barbarism felt itself seriously threatened.» (Nouvelle-Calédonie et Dépendances, 1918: 412ff)

In this kind of analysis, there were only minor qualifications to the presumption that race was the primary cause of conflict. The Kanak «rebels» were identified as those who had not yet been civilised or who had remained independent; this was an analysis which implied that civilisation and greater administrative control would remove the possibility of future revolt (Repiquet, 1917).

The conquest remained unofficial, but there was an implicit recognition of sorts in 1905 and 1917. In October 1917, the Ministry of Colonies refused to accept the financial burden of the 1917-1918 war on the grounds that the «expenses occasioned by the repression of troubles» had been charged to «local budgets» rather than to the French parliament since January 1905. The circular which had accompanied the 1905 decision had stated that the era of colonial «conquest» and «pacification» was over and that «the allocation of regular troops must have for its principal, and for that matter only, aim the repulsion of an attack coming from the exterior $\rangle^{7}$. This bureaucratic logic informed the denial that the confrontation between Kanak and colonial authorities in 1917 might be considered as an act of war or insurrection; instead it was to be seen as a series of crimes, one of which was the act of rebellion (Muckle, 2004: 303-319).

In the 1940s and 1950s, European accounts of colonisation and settlement made only passing reference to earlier wars and what might have caused them. In 1953, many New Caledonians celebrated one hundred years of French rule. Several publications commemorated this event and took the opportunity to reflect upon the beginnings and future of the colony. Commissioned by the Conseil général, Le livre du centenaire 1853-1953, by expatriate writer Jean Mariotti, presented New Caledonia as the «last land discovered» and a symbol for all human endeavour related to the search for knowledge of oneself and the surrounding world (Mariotti, 1953: 13). Le livre du centenaire devoted considerable space to this European discovery and the divergent experiences of Cook and d'Entrecasteaux upon first contact with Kanaks, but made only passing reference to conflicts such as the 1878 war and the process of pacification. Mariotti described New Caledonia as a fragile land whose plants and people had fought to withstand the «avalanche» of contact before finding an equilibrium:

«All of this did not take place without some opposition. Cyclones and floods often put everything in

any problems with Aborigines, they have killed them all'. That's what the history of conquering peoples is like and you don't rewrite History unless you have nothing better to do» (Lafleur, 2000: 85-86).

7. Le sous-intendant militaire de $2^{\mathrm{e}}$ classe P. Lippman (directeur de l'Intendance du Groupe du Pacifique) à M. l'Inspecteur (chef de Mission) $\mathrm{n}^{\circ}$ 208, Nouméa le 20 mars 1919, carton AFF POL (Affaires politiques) 742, CAOM (Centre des archives d'outre-mer, Aix-en-Provence). 
question. Certain plants that were thought to be useful were found to be nuisances. The great Insurrection of 1878 threatened to compromise the enterprise undertaken. Many were the chiefs and natives, like the Great Caké and his war-chief Nondo, who rallied to the sides of the Europeans.

Plants and men fought before finding their balance. [...] The whole island is pacified and fertile. (idem: 82)

While this publication was certainly progressive in the context of its times, the pertinent point here is the tendency to naturalise the conflict that occurred as a result of colonisation. Conflict with Kanaks was assimilated to the realm of the environment and the category of natural disasters in much the same way as earlier colonial publicists had fitted descriptions of the «Native mœurs» between accounts of «Shelters and routes of communication» and «Meteorological perturbations» (Delabaume, 1886) ${ }^{8}$.

After 1975, when the colonial enterprise was again unsettled, this time by calls for independence, local historians had difficulty finding their own words to describe or explain past conflicts. Rather than attempt their own revision of colonial histories, they reverted to the words of earlier writers. On the centenary of the 1878 war, at a time when political divisions were widening, the Société d'études historiques de la Nouvelle Calédonie (SEHNC), published a document by Vitte, the Catholic bishop to New Caledonia from 1874 until 1878 (SEHNC, 1978). Vitte believed that discussion of the so-called secondary causes of war had been exaggerated by critics of settlers and the local administration and that the principal cause was that Kanaks had not been christianised. In the foreword to a history of the 1878 war by Linda Latham, an Australian history student, Barbançon underlined the vision which the SEHNC wished to defend: «Contacts were constant and friendly between the two ethnic groups: they were not the relations of the oppressors to the oppressed» (Barbançon, 1978: 4-5; Latham, 1978). In the 1980s, as political tensions grew, discussions of past conflicts were generally avoided; contributors to the SEHNC's bulletin privileged narratives of progress, discovery, exploration and pioneering; they looked back to the age of pioneers and explorers (Aldrich, 1989: 25-27).

Notwithstanding official denials (and an insistence upon legality and good intent), earlier unofficial representations of colonisation and settlement have recognised a process of conquest and invasion. Past analyses of conflict were not backward in calling into question, or acknowledging the violence of, colonial processes and the immediate causes of conflict with Kanaks, but these were invariably made subordinate to overriding laws or principles such as race or civilisation, or an argument about the absence of civilisation or christianisation. From this perspective, the language of the preamble to the Noumea Accord does not represent any significant departure or reappraisal; if anything it forms part of the ongoing denial of colonial processes and the challenges to them. This is not to say that it ignores past violence altogether; in the two following sections I consider how the agents of colonisation and moments of violence have been represented.

\section{The colonial masquerade}

The preamble to the Noumea Accord makes a significant distinction between different categories of immigrants. In its second section, colonisation is described as:

«part of a broad historical movement which saw the European countries impose their domination on the rest of the world. In the $\mathrm{XIX}^{\text {th }}$ and $\mathrm{xx}^{\text {th }}$ centuries, many men and women came, either with the conviction that they were bringing progress, or inspired by their religious faith, or sent against their will or seeking a second chance in New Caledonia. [...] Some of them, especially the cultured people, priests and pastors, doctors and engineers, administrators, soldiers and political leaders, looked differently upon the original inhabitants, showing greater understanding and genuine compassion.»

These people brought the «scientific and technical knowledge» which made «mining and agricultural activity» possible and «made it possible to lay a foundation for development» (Noumea Accord, 1998).

We are told, therefore, that «cultured people» showed more compassion and understanding for Kanaks than the other men and women who simply came, sometimes «against their will», with «hopes» and «illusions». It is to be noted that there is no particular mention of other categories of non-Kanak settlers: convicts, indentured labourers, traders, planters, pastoralists or miners. Though the word settler or colonist is avoided, there is an implicit division between those whose presence was permanent (or landed)

8. In earlier writing (e.g., the short story «Paysage») Mariotti did evoke conflicts such as the war of 1917-1918. In this instance, too, such conflict was seen as in many respects inevitable, though Mariotti frankly acknowledges the role of the coloniser: «these people were the children of the countryside that I tread as a foreigner - even though born on the Island» (Mariotti, 2000: 59). 
and those whose presence was, perhaps, less permanent. This distinction (or imbalance) points to a colonial double-standard, a distancing of Metropolitan France from colonial responsibility. It implicitly denies that the latter might also have been capable of understanding or compassion and suggests that the former were untainted by the excesses of colonisation or colonialism. Like the difference between dispossession and conquest, this distinction also has a long lineage in the shifting relationships between Kanaks, settlers, administrators and the French state.

Explanations of the 1878 war reflected differences in the way that settlers, administrators and representatives of the French State saw the relationship between Kanaks and settlers. Explanations which exonerated settlers and administrators were rejected by the 1879 Trentinian inquiry which found that the war was the result of settler provocation and that the local administration ought to have foreseen «the invasion of the whites» and ought to have advised them to be «more prudent» in their relations with Kanaks (Nouvelle-Calédonie et Dépendances, [1879]).

Trentinian's report famously remained unpublished until 1965, but in the 1880s and 1890s the suggestion that settlers had invited or provoked Kanak acts of aggression was a consistent theme in administrative reports and in the manuals written for settlers that stressed the importance of treating Kanaks fairly. The only settlers who had anything to fear, it was said, were those who failed to treat Kanaks with respect (e.g. Delabaume, 1886: 21-22; Daville, 1901: 165; Savoie, 1922: 9; cf. Muckle, 2002). The sensitivity of administrators to career-damaging criticism prompted them to insist upon the danger represented by convicts or settlers and the need to police the boundaries separating colonial categories more effectively. The administration refused to allow the formation of settler militias and the relations formed between freed convicts and Kanaks were viewed with distrust. Despite the cessation of transportation in 1897 and the dwindling of their numbers, convicts and their descendants were viewed with considerable suspicion well into the first decades of the twentieth century as «a suspicious mass of individuals whose immoral instincts have already brought them to the bagne and who would be capable of the worst excesses»»?.

After the 1917 war, officials sought to distance themselves from the actions of settlers. Governor Repiquet, fearing that the failings of his administration might be found to blame, told his superiors in Paris that Kanak hatred had been directed against settlers, rather than the administration:

«They [Kanaks] wanted, once more, the yoke of the invader, taking it out less against the Administration which they know to be kind than against the settler in whom they see their enemy.» (Repiquet, 1917)

The effect of such argumentation was to draw attention away from the responsibility of administrators and the limited authority they had managed to exercise over frontier relations in general.

Settlers and their representatives railed against administrative criticism and suggestions that their own actions might be at fault. In 1885, the settler delegate in Paris, Léon Moncelon, rejected claims «that Canaque revolts were motivated by the theft of women, the invasion of cattle or the brutality of settlers». He argued that Kanak women who lived with settlers were looking for «liberty» and that settlers generally treated Kanaks as «big children» despite evidence of their «ferocious» instincts in land matters. According to this argument, it was the administration which had failed to take serious measures for the protection of settlers or the assimilation of «the Canaque race» (Moncelon, 1885). Similar arguments would be made by settlers after the war of 1917-1918 (Muckle, 2004: 319-329).

The disdain and contempt shown by administrators made its mark on those settlers and their descendants who came to see themselves as (New) Caledonians (Vermast, [c.1900]) ${ }^{10}$. In 1942, the author of Pioneer Days, Hélène Lainé, referred to "the resentment of Caledonians at the prejudiced utterances of Metropolitans» that were based on "pre-conceived notions» rather than «on friendship for or on knowledge of this country (Lainé, 1942: 79). Though demands for greater autonomy did not have any success until the 1950s, it was partly in reaction to these stereotypes that settlers asserted pioneer traditions, some of which looked beyond the

9. Gouverneur to M. le ministre des Colonies, $\mathrm{n}^{\circ}$ 1068, Nouméa le 2 oct. 1907, carton Nouvelle-Calédonie 207, CAOM.

10. Vermast's account of the experiences of a family of Flemish settlers and their passage from struggling farmers to wealthy mine owners demonstrates that settlers already had begun to mythologise themselves as «workers of the first hour» (Vermast, [c.1900]: 127) and the builders of a future that was New Caledonian rather than European. The novel ended on this sentence: «My husband gets angry when he hears colonists complaining of nostalgia for the fatherland overseas and he tosses them a Latin locution which should be, he says, the supreme consolation for all colonists: Ubi bene, ibi patria! There, where one is comfortable, that's where the fatherland is!» (idem: 128). 
frame of French colonisation to the first English traders. Lainé's account of Pioneer Days drew upon a dual heritage, that of a great grandmother, who had emigrated to New Caledonia from Ireland by way of Australia, and that of a Breton grandfather, killed in the 1878 war. In Les confidences d'un cannibale (first published in 1966), a semi-historical narrative of settlement in the form of a fictional dialogue between a settler and a former «cannibal», Paul Bloc stressed the values brought by «good» or «true» pioneers and colonists, notably Paddon and Higginson, certain communards and the free settlers who came under Governor Feillet. Bloc placed great emphasis on the divisions that existed between whites and the need to see people as individuals (both good and bad) rather than in terms of blacks and whites (Bloc, 1998: 81).

In the 1960s and 1970s, Kanaks were generous to local settlers in their public representations of the havoc wrought by colonisation as well as in their apportioning of responsibility between different categories of Europeans. In his 1963 study of the 1878 war, Kanak Catholic priest, Apollinaire Anova-Ataba, cast the Kanak leader, Ataï, as a hero, and the French colonel, GallyPasseboc, as a genocidal villain. Perceiving the political reversal of 1963 as a return to colonialism, Ataba attempted to establish a common ground between the «European» and the «native», in opposition to the "Metropolitan» (Anova-Ataba, 1969: 219). Settlers, he wrote, had to overcome their sense of «inferiority in relation to the Metropolitan» by acknowledging the heritage of transportation and deportation.

«The native must be proud of the one who was the soul of the Insurrection of 1878: the great chief Ataï. He must see in him the symbol, "the incarnation" of the person who must be his model in the construction of his country. The European must not deny those who built churches, traced roads, and built schools and hospitals. They are also pioneers. We owe them our admiration and profound respect.» (idem: 202)

Rather than attacking the pioneer mythology, Ataba suggested that it be expanded and be made more inclusive.

In 1975, the performers of Kanaké, a drama or jeu scénique performed at the Melanesia 2000 festival, wore the masks of a missionary, a soldier and a trader to represent les hommes blancs. In the play's final act «The masks are torn away, it is no longer the mannequins who speak, but authentic men». According to the performance programme:
«It is time that the relationship conquerorscolonised be forgotten, it is time that a new relationship be put in place, that which presided over the traditional exchange of yams [...]» (Melanesia 2000, 1975: 17)

Although this was intended as a gesture of reconciliation, the descendants of the settlers saw no need to respond to what they saw as folkloric demonstrations of Melanesian culture and failed to recognise themselves in the colonial trinity of trade, war and religion (I. Kurtovitch, 1995; Barbançon, 1995: 166). Their forbearers were just as likely to have been convicts, coffee planters or cattle raisers. As noted by Isabelle Merle in her study of the formation of colonial identities, the descendants of free settlers do not see themselves or their forbearers as implicated in the history of cantonnement or refoulement which generally preceded their arrival (Merle, 1995: 356). This sentiment has been articulated most recently by the RPCR leader, Jacques Lafleur, who has claimed «that there was nobody who really carried any responsibility for colonisation» and that «So-called colonial behaviours are due to France and its administration» (Lafleur, 2000: 85-86 and 218).

In the 1980s, the political discourse of the independence movement, in accordance with the worsening political situation, became less compromising towards settler communities. JeanMarie Tjibaou was now convinced that Kanaks had to seek recognition from Metropolitan France rather than from the increasingly hostile settler community, in order to obtain independence. This quest culminated in the 1983 roundtable at Nainville-les-roches and the recognition, by the French State, that Kanaks had an «innate and active right to independence». In 1984, after the creation of the FLNKS and the establishment of a provisional government, prominent leaders such as Tjibaou and Hnalaine Uregei said that Kanaks were prepared to acknowledge members of the settler community as «victims of history» (Tjibaou, 1996: 184; Uregei, 1984: 7). In «Lower the masks» («Bas les masques»), a poem written in 1974, but published in 1985, FLNKS militant, Déwé Gorodé ${ }^{11}$, called upon Europeans to lay down the masks they had been wearing for more than a century and to allow Kanaks to «return to the forefront in and of our history»:

«Finished the masquerade / of the uprooted without names suddenly appearing / from the West greedy for primary materials. / [...] Superstars / mariner sandalwooder priest / Characters / soldier gover-

11. A former member of the Foulards Rouges and member of the Parti de Libération Kanak (Palika), Déwé Gorodé is currently the Vice-President of the New Caledonian Government. 
nor convict / settler merchant pastor. / Chorus of extras / my proud warrior people naked / without mask / struck fallen exiled / standing rebel militant / combatant / [...] Lower the masks [...].»

Gorodé called for a future in which Kanaks might be something more than extras, rebels or combatants and in which non-Kanaks would set aside their many masks to reveal their own individual or shared identities (Gorodé, 1985: 98-99).

After 1984, in the context of the intensifying conflict between supporters and opponents of independence, writer Nicolas Kurtovitch, the descendant of both a missionary and a trader, used the voice of a world traveller to trace his roots to a European heritage shared with a Viking «fighting against Roman law», the descendants of Attila the Hun and Genghis Kahn. ${ }^{12}$ In the poem «Frontiers» («Frontières»), he approached Anova-Ataba's ideal of recognising Atai as the symbol of a shared past, finding common cause with Atai and all other resistance to the West:

«I am at every moment / With Ataï / Thrown with madness with courage / With faith and strength from the land / Against the western hordes.» (N. Kurtovitch, 1985: 45-47)

The poem ended with a renunciation of Europe when the traveller discovered both that he was «gaulois» and that the successors of Vercingétorix were unworthy of him (48-50). This represented a significant and progressive attempt to establish a middle ground between people of Kanak and settler descent.

In 1987, an historical novel, La terre violente, explicitly highlighted tensions between Kanaks, settlers, métis and Metropolitan French. The novel, by Metropolitan author Jacquéline Sénès, relates the history of New Caledonia through the changing fortunes of the Suttons, a settler family of Irish descent. Sénès grounds the Sutton family, characterised as pioneers, in traditions outside of the frame of French colonisation, but the family becomes caught up in the history of the country whose turning points become their own. The Suttons embody an agrarian ideal, living on the land in close proximity to Kanaks. Héléna, the family matriarch, is haunted by the memory of a Kanak attack in 1878, but it is the métis, Wanatcha, who develops a virulent hatred for his mother's people, and in particular the «sorcerer» of the neighbouring reserve, whom he eventually kills-suggesting that the dreams of romantics or idealists are corrupted or perverted by colonial relationships (Sénès, 1987: 138-140). The eldest son, Dick, leaves the family station to fight in World War One and later returns to live in Noumea with his French wife, Maximilienne. As her imperious name suggests, Maximilienne represents an uncompromising Metropolitan France which stifles the personality of her husband who ultimately commits suicide. Yet, Maximilienne is also an idealistic teacher determined to inculcate French values into her adopted Kanak son, Jean-Chrétien, reject the colonial world of her husband and promote greater autonomy. Trained in the seminary (like independence leader Jean-Marie Tjibaou), the idealistic JeanChrétien eventually renounces his mother's culture to fight for independence against monopoly capitalism and rediscover his own culture (Sénès, 1987).

The unforgiving portrayal of the métis in $L a$ terre violente is a reminder that racial categories form another less publicly acknowledged strand of categories, the constitution of which has varied according to time and circumstance. Unlike some other French colonies, métis, persons of mixed race, did not form a separate social group in New Caledonia and were treated as either European citizens or Kanak subjects (indigènes) depending on their own selfidentification and recognition of European paternity. In 1915-1917, métis were mobilised to fight in the Great War as French citizens (whereas Kanaks, as French subjects, could only be asked to volunteer) and in the 1983 census métis could only be classified as Europeans. In 1987, however, state officials determined to distance themselves from responsibility for the 1984 massacre of ten Kanaks in the Hienghène valley, insisted upon identifying those responsible as métis (Connell, 1987: 236-237; Douglas, 1996). This recalled the tradition whereby administrators sought to distance themselves from responsibility for acts of violence on the frontier by attributing them to the clash of races or undesirable elements.

The use of an array of categories to identify those who participated in the history of colonisation is a potentially useful antidote to simplistic dualisms (black versus white, European versus Kanak, coloniser versus colonised) but these categories may also be masks; they protect the reputation of the wearer, but they also distance him or her from the audience; they can conceal individual differences as well as shared identities.

12. Nicolas Kurtovitch has identified himself as a descendant of Jean Taragnat (1816-1878), one of New Caledonia's early missionaries and entrepreneurs (N. Kurtovitch, 1998). 
In the preamble to the Noumea Accord, it would seem that the masks worn by the «cultured people» have not been lowered, that those worn by others have not been recognised or named and that Kanak masks are completely invisible. This perpetuates an ongoing opposition between those who insist upon the humanitarian concerns of an educated and cultured elite (and refuse to acknowledge the structural role of such elites in colonial projects) and those who insist that colonisation or colonial behaviours were due to France and the colonial administration and that settlers themselves had, or have, no part in this. These different categories may be considered as signs of the structural presence of colonialism and competing colonial discourses; there were real antagonisms between, for example, settlers and administrators and these shifted according to power relations, but the emphasis placed on them seems overstated and denies the possibility that understandings might be formed between other individuals or groups as well.

\section{Fatal misunderstandings}

In the third section of the preamble to the Noumea Accord, the signatories recognise «the shadows of the colonial period even if it was not completely devoid of light». These shadows resulted from the «impact of colonisation» in which Kanaks were deprived of their identity, dignity and resources:

«The Kanaks were relegated to the geographical, economic and political fringes of their own country, which, in a proud people not without warrior traditions, could not but cause revolts, which were violently put down, aggravating resentment and misunderstanding.»

The restoration of this «confiscated identity» is said to be a recognition of Kanak «sovereignty» and a step towards «the forging of a new sovereignty, shared in a common destiny» (Noumea Accord, 1998).

In this account of marginalisation, Kanaks appear as passive, or at best rebellious, with no active role in the development of the territory. Though «proud» and warlike, Kanaks reacted against unnamed aggressors and in turn became the victims of the repressive violence incited by their own «revolts». The basic condition of the relationship between Kanaks and the other unnamed parties is described as «resentment» and «misunderstanding». Closely associated with this is the assertion, discussed in the previous section, that a cultured elite showed greater understanding of Kanaks.
Assertions about the capacity of different groups to reason, imagine or understand one another have been important rhetorical weapons, especially in attempts to explain conflict. After the 1878 war, settlers and administrators denigrated Kanaks as unthinking creatures or savages. Rivière, for example, saw Kanaks as savages who were governed by «sudden, violent and irresistible sensations» (Rivière, 1881: 131132) and thought of the 1878 war as a necessary part of a process in which Kanaks, «giving themselves up without a care for the past and without regard for the future to the immediate sensations awakened within, [...] will fight each other according to the ebb and flow of these sensations and to the benefit of their common enemy» (idem: 280-281). This was a denial of both Kanak resistance and the pragmatic support offered by Kanak chiefs to the administration and a forerunner of the trope of Kanak resistance as involuntary spasm, last gasp or death throe.

The reasons for denying Kanaks a degree of conscious agency have varied. In the court cases which followed conflicts in 1867 and 1917, the idea that Kanaks had blindly followed the orders of malevolent chiefs was an argument used by the lawyers charged to defend them (Moniteur de la Nouvelle-Calédonie..., 5/01/1868; La France Australe, 18/09/1919). Such a denial could also imply a condemnation of violence as a means for challenging colonial injustice. Although he acknowledged that Kanaks had legitimate grievances, the Protestant missionary and ethnologist Maurice Leenhardt saw no sign that Kanaks who chose to fight in 1917 had any reasoned or coherent objectives:

«They acted as if moved by an incoherent and intimate force which arose from within them and their desecrated valleys, and unable to move beyond these narrow horizons; a fight without a goal and without hope, spasm of the holders of an outdated orthodoxy.» (Leenhardt, 1953: 207)

In 1953, similar views were implicit in Jean Mariotti's assimilation of frontier conflict with the cyclones and floods that perennially destroyed Kanak and settler plantations (Mariotti, 1953: 82). A decade later, Anova-Ataba portrayed «1878» as a struggle for existence between «two worlds» which he likened to «two gladiators pushed by an invisible force which is foreign to them, fighting to the death, eyes blindfolded, without really knowing why» (Anova-Ataba, 1969: 209-210). That neither gladiator was fully conscious of, or responsible for, his or her actions shifted the attention away from the acts of violence and lists of victims which earlier 
settler accounts had painstakingly catalogued (e.g. [Anon.], 1882; Savoie, 1922).

The idea that human behaviour was subject to powerful external forces was not unlike the discourse of savagery in which Kanaks were represented as little better than vindictive or murderous creatures, but the novelty in Anova-Ataba's account was to share the idea of inanity, of senselessness and undeveloped intelligence, between Kanaks and Europeans. According to Anova-Ataba, Kanaks in 1878 had not yet acquired a «Cartesian» outlook and made no distinction between the individual and the group when responding to the actions of settlers. On the other hand, settlers and convicts, especially the communard deportees, had inherited «the individualist spirit of the First Republic» (Anova-Ataba, 1969: 209-212). Whereas Rivière had written that in 1878 the communards had overcome the "sad hatreds in their hearts» to defend their «land of exile» as if it were France (Rivière, 1881: 121), Ataba saw a European figure marked by a "sense of injustice and frustration» which could only be compensated for by a desperate "vengeance» (Anova-Ataba, 1969: 212). In so far as Ataba's characterisation of the deportees was based upon a portrait of Louise Michel, one of the few communards who had shown support for Kanaks (by giving part of a red scarf, a symbol of the Paris Commune, to a Kanak who joined the war), this may also be seen as an attempt to look outside the principal frame of French colonisation to an exceptional gesture of understanding (cf. Michel, 1970: 147148). Significantly, it was this gesture that became a symbol for a Kanak political party of anti-colonial persuasion, the Foulards Rouges, in the early 1970 s.

Metropolitan writers who were sympathetic to Kanaks were less balanced in their apportioning of intelligence than Anova-Ataba. Roselène Dousset-Leenhardt, the daughter of Maurice Leenhardt, sought to identify a Kanak aesthetic and a Kanak history of resistance in her two studies of colonial conflict in New Caledonia: Colonialisme et contradiction $\left(1970-1^{\text {st }}\right.$ published 1965) and Terre natale, terre d'exil (1976). Dousset's understanding of colonialism was based upon that of Octave Mannoni, a colonial theorist who believed that colonial racism was not the product of European civilisation but of the «mediocre» Europeans who toiled with little success in the colonies (Mannoni, 1950: 16; Dousset, 1970: 27). According to Dousset, colonialism had prevented Europeans from recogni- sing Melanesians and this had in turn led to conflict:

«It was in the logic of colonialism to deny the reality of this civilisation, inevitably provoking its opposition, rebelliousness, which was the only expression henceforth possible of the vital need, common to all groups and societies, to defend the authenticity of their culture, and which will become more intense as the society attacked is more civilised.» (Dousset, 1970: 105)

Dousset went on to suggest that the «original antinomy» and the failure to recognise «the New Caledonian civilisation» was due to a «lack of imagination» on the part of «the whites» (Dousset, 1970: 21, 107). However, she defended the «objective» appreciation of Kanak values brought by the soldiers and naval personnel, who had shown a capacity for «mutual understandings», and the Governors who had done all that they could in a «difficult situation» (Dousset, 1970: 27, 99; Dousset, 1976: 181). This defence of well-intentioned administrators led Dousset to a surprising characterisation of the French Colonel, Gally-Passeboc. Whereas Anova-Ataba saw Passeboc as a «fierce colonialist who wished for the extermination of the native race», Dousset saw him through colonial texts as «the person in the world who perhaps loved the natives the most» (Anova-Ataba, 1969: 215; DoussetLeenhardt, 1976: 62-63).

While Dousset sought to valorise a Kanak civilisation through a history of resistance, others appealed to a Metropolitan sense of the exotic and uncertainty regarding the benefits of European civilisation. In a postscript to Dousset's Terre natale..., a history of the 1878 war, the contrast between Kanak and settlers was vividly painted by Etienne Souriau, an aesthetician at the Sorbonne ${ }^{13}$. On the one hand there were Kanaks: «[a] dark bronze race, solid, harmonious, enamoured with beauty, noble in gesture and thought»; on the other hand, the convicts, «this deplorable sample of the white race», and settlers:

«Hardened and enterprising men, come from afar who thought to improve countries submerged in barbarism. [...] Amongst them, here and there, some men of the elite. But considered all together as colonials they were somewhat brutal and uncultured.» (Souriau, 1976: 253)

According to Souriau, the gulf between Kanak and settler could only be bridged by «the invention of a common universe as valid for the

13. Étienne Souriau, a professor of aesthetics at the Sorbonne was the son-in-law of Marc le Goupils (1860-1942) who lived in New Caledonia for six years and later published several accounts of his experiences as a settler. 
white as for the Melanesian». This, he believed, would require «a kind of poetic imagination», but while «the most valuable practical contributions» to this imagination would come from the «Melanesian soul», the «whites» were still a long way from being able to contribute (idem: 255).

A decade later, the Kanak argument that settlers were blinded from seeing or understanding Kanaks reflected frustration with attempts to make progress on the question of independence and the hostility or racism of the settler community. Tjibaou maintained that the «Cartesian mind» severely limited the French understanding of the South Pacific and their ability to imagine a South Pacific future (Tjibaou quoted in Robie, 1989: 102). This was more than a failure of the imagination: the Caldoches were «an impoverished people, a people without a culture [who] reject Kanaks just as they reject the (Metropolitan) French» (Tjibaou, in Fraser, 1990: 11).

These critiques of the settler community in particular appealed to, and played on, the long history of Metropolitan contempt for convicts or rough colonials of dubious origins, but settlers in turn drew on long traditions of skeptical contempt for what were, in their view, the often unrealistic, idealistic or romantic ideas held by those with little actual experience of New Caledonia. Settlers and their descendants staked a claim to knowledge; they claimed that they knew Kanaks best and that they had a demonstrated capacity for understanding. As noted above, members of the SEHNC steadfastly defended the conviction that past relations between Kanaks and settlers had been friendly (Barbançon, 1978: 4-5) and that settlers knew and understood Kanaks better than Metropolitans. The defence of settler virtue, of the humanity of past colonial relationships, was taken further by Paul Griscelli who rejected the suggestion that the death of his grandparents, at the hands of Kanaks in the 1917 war, could be related to their involvement in the surprise arrest of a Kanak chief (Saussol, 1979: 318). Griscelli insisted that relations between his grandfather and local Kanaks had been friendly and that settlers had been innocent victims in a war between Kanaks. The reputation of settlers was to be defended, but without any serious consideration of Kanak grievances or the violence of relations on the frontier (Griscelli, 1982 and 1989). This insistence upon the idea of friendly relations can be compared with Alaine Chanter's analysis of the way in which images of "serenity» or harmony between settlers and the natural environment were used in the conservative press to legitimise acts of violence against Kanaks in the 1980s (Chanter, 2000: 67).

In the 1980s, an increase in the level of violence and the determination of Kanak leaders, especially Tjibaou, to challenge universalising discourses and stress Kanak difference unsettled European sympathisers. Nicolas Kurtovitch who earlier had been prepared to acknowledge Ataï as a figurehead in a shared struggle, complained that masks of difference were barriers to communication and dialogue. In the poem «Blood» («Sang»), he maintained that hatred was dictated by ignorance and that it had removed hope. There was no «wealth» in difference only «denial and violence» (Kurtovitch, c.1988: 13). In «Where are they going like that?» («Oì vont-ils ainsi ?») violence is explained in terms of exclusion and ignorance or the failure to know the other:

«If the police shoot first and talk later it is because they are ignorant of the patterns, the signs, the smiles and also the sensations like embracing a woman [...].»

Echoing the appeal made in Gorodé's poem, «Lower the masks», Kurtovitch, called upon people to:

«Lower the masks when you touch the stomach that you embrace and inflame a heart

The truth must shake up in a single movement the city taken by storm

$[\ldots]$

Lower the masks and use

a simple and direct language

I am not heard very well no better than anyone else and like them I wear

different faces at different times

And some take

My face for a mask.»

(Kurtovitch, c.1988: 62-66; cf. Gorodé, 1985: 98-99)

Misunderstanding and incomprehension have been convenient, but unhelpful, euphemisms for explaining conflict. While it may be appropriate for an official political document, such as the Nouméa Accord, to seek to reconcile opposing points of view and to reach a compromise in order to move forward, it is also important to ask what people did understand about each other in the past and how they related to each other at both individual and institutional levels. The representation of people as actors or roleplayers - as if they were participants in a scripted or masked drama - means that they are not likely to be seen as agents of their own destiny, as taking decisions which were rational or strategic if seen in their historical context. Ironically, this is something which lawyers did when defending Kanaks after the war of 1917-1918; they argued 
that Kanaks had fought a war for independence (Muckle, 2004: 334).

In the preamble to the Noumea Accord, France and the non-Kanak community accept the fact of colonisation, acknowledge the dispossession of Kanaks and recognise a Kanak identity. Kanaks acknowledge the historical context in which possession was declared, that some colonisers were more compassionate than others and that the new communities made an important contribution to the country's development. This is the rhetorical (or in a sense historical) foundation upon which a shared future is to be built. As I have noted, there have been other attempts to lay foundations for shared futures. Some of the sites chosen include: first contact with Cook or the "good» pioneers who followed; Louise Michel's red scarf; the understanding and compassion shown by «cultured» people and the possibility of a shared past as victims of oppression. The preamble itself refers to World War One where Kanaks and settlers both fought for France (Noumea Accord, 1998).

The main difference between the preamble to the Noumea Accord and earlier representations of French colonisation is the emphasis the Accord places upon the possibility of a shared future and the recognition of the Kanak identity. It does not, however, involve a radical reappraisal of the past. It certainly does not appear to suggest, for example, the presence of any decolonising movement that might involve putting in place new sources of authority and placing distance between colony and Metropole. Not surprisingly, given its political function, the preamble reinforces Metropolitan French authority and privileges the overarching narratives of the sort that legitimised colonisation (denying the legitimacy or reason of Kanak resistance) and which attenuated the responsibility of either colonial administrators or settlers. The recognition of the impact of colonisation in the Nouméa Accord is not remarkable; this recognition was also a feature of earlier representations of conflict as a natural or inevitable consequence of European colonisation or settlement. Rather than insist upon the understanding or compassion shown by particular categories of immigrants, it would seem to be more important to consider precisely what was understood. It is all too easy to say that the preamble and the Accord itself have achieved a decolonisation when they are really only another starting point for such a process; in order to better understand the present, the shadows of the past still need to be explored.

\section{BIBLIOGRAPHY}

Aldrich Robert, 1989. The Place of New Caledonia in French Historiography, in Spencer, M. et al. (eds), New Caledonia: Essays in Nationalism and Dependency, St Lucia, University of Queensland Press, pp. 22-37.

[ANONyme] 1864. Note sur la Nouvelle-Calédonie destinée à servir d'instruction aux colons immigrants dans cette colonie, Paris, Librairie de Challamel.

[ANONYme] 1882. [Nouvelle Calédonie. Insurrection des tribus canaques des circonscriptions de Bouloupari à Koné. Massacres des 26 et 27 juin [sic] et 11 septembre 1878. Listes nominatives des victimes.] Nouméa, Imprimerie civile.

Anova-Ataba Apollinaire, 1969. Deux exemples de réflexions mélanésiennes. 1. L'Insurrection des Néo-Calédoniennes en 1878 et la Personnalité du Grand Chef Atai. 2. Pour une Économie humaine, Journal de la Société des Océanistes 25, pp. 201-237.

Angleviel Fréderic, 2002. L'histoire en NouvelleCalédonie. D'une mémoire occultée à une approche identitaire duelle, in Les pays du Pacifique en crise : ̀̀ la recherche de l'unité dans la multiplicité, Le Havre, Centre d'études du Pacifique et L'Harmattan, pp. 171-193.

Archembault Marius, 1904. La colonisation et la question indigène en Nouvelle-Calédonie, Paris, Librairie Charles.

BARBANÇON Louis-José, 1978. [Foreword], in Latham L., La révolte de 1878. Étude critique des causes de la rébellion de 1878 en Nouvelle-Calédonie, Nouméa, SEHNC, pp. 4-5.

_, 1992. Le pays du non-dit : regards sur la NouvelleCalédonie, La Mothe-Achard, Offset Cinq Édition.

_, 1995. La terre du lézard, Nouméa, Île de Lumière.

Berman Alan, 2001. The Noumea accords: Emancipation or colonial harness?, Texas International Law Journal 36, 2, pp. 277-298.

BLoc Paul, 1998 ( $1^{\text {st }}$ published 1966). Les confidences d'un cannibal, Nouméa, Île de Lumière.

BoengKiH Jacques S., 1994 (oct.). Kanaky; an open letter, Pacific News Bulletin 9, 10, p. 2.

CHANTER Alaine, 1999. Will there be a morning after? The colonial history of the media in New Caledonia, Journal of Pacific History 34, 1, pp. 91-108.

—, 2000. The production of social disorder: the example of the daily press in New Caledonia, in Dinnen, Sinclair and A. Ley (eds), Reflections on Violence in Melanesia, Leichardt, Hawkins Press and Asia Pacific Press, pp. 65-79.

_, 2002. Postcolonial politics and colonial media Representations in New Caledonia, Pacific Studies 25, 3, pp. 17-36.

Chappell David, 1999. The Noumea Accord: Decolonization without independence in New Caledonia, Pacific Affairs 72, 3, pp. 373-391. 
Chesneaux Jean, 1981 (dec.). Can two opposite views of the past be turned into one in the future? Pacific Islands Monthly, pp. 24-27.

Connell John, 1987. New Caledonia or Independant Kanaky? The Political History of a French Colony, Canberra, National Centre for Development Studies.

DAHLEm Jacqueline, 1996. Nouvelle-Calédonie, pays kanak : un récit, deux histoires, collection Sémantiques, Paris, L'Harmattan.

Daville Ernest, 1901 ( $2^{\mathrm{e}}$ éd.). Guide Pratique du Colon en Nouvelle-Calédonie, Paris, Librairie africaine et coloniale.

Delabaume Paul, 1886. La Nouvelle-Calédonie devant la France, Paris, Imprimerie et Librairie centrales des chemins de fer, Imprimerie Chaix.

Douglas Bronwen, 1996. Reflections on political murder: New Caledonia, 1984, in Denoon D. (ed.), Emerging from Empire? Decolonisation in the Pacific, Proceedings of a Workshop at the Australian National University, December 1996, Canberra, Division of Pacific and Asian History, RSPAS, ANU, pp. 69-72.

Dousset Roselène, 1970 ( $1^{\mathrm{e}}$ éd. 1965). Colonialisme et contradictions. Étude sur les causes socio-historiques de l'insurrection de 1878 en Nouvelle-Calédonie, Paris, Mouton.

Dousset-LeEnHARDT Roselène, 1976. Terre natale. Terre d'exil, Paris, Maisonneuve et Larose.

FAure-Biquet Paul, 1876. Géographie de la NouvelleCalédonie, Paris, Lassailly frères.

Fraser Helen, 1990 (jan.). Man of the Decade, Pacific Islands Monthly 60, 1, p. 11.

Gorodé Déwé, 1985. Sous les cendres des conques, Nouméa, Édipop.

Griscelli Paul, 1982. Le Massacre des Grassin (rébellion de 1917), Bulletin de la société d'études historiques de la Nouvelle-Calédonie 51, pp. 33-42.

GrisCELli Paul, 1989. Et voilà comment on écrit l'histoire, mise au point à propos de Hienghène le désespoir calédonien (L. Duroy), Bulletin de la société d'études historiques de la Nouvelle-Calédonie 79. pp. 73-75.

Jouve Dominique, 1997. Some Imaginary Dimensions of the Political Discourse in New Caledonia, in Aldrich R. and I. Merle (eds), France Abroad: Indochina, New Caledonia, Wallis and Futuna, Mayotte, Sydney, University of Sydney, pp. 79-96.

KuRtovitch Ismet, 1995. Sur la signification de Mélanésia 2000 en milieu européen, Mwà véé 10, pp. 4243.

Kurtovitch Nicolas, 1985. Souffles de la Nuit, Paris, Éditions Saint-Germain-des-Près.

—, c. 1988. L'Arme qui me fera vaincre, Éditions Vents du Sud.

LAFLEUR Jacques, 2000. L'assiégé : 25 ans de vie politique. Une histoire partagée avec la NouvelleCalédonie, Paris, Plon.
LaINÉ Hélène, 1942. Pioneer Days in New Caledonia. A Story of Pacific Island Settlement, edited and translated by H.E.L Priday, Nouméa, Imprimeries réunies.

LAтнам Linda, 1978. La Révolte de 1878. Étude critique des causes de la rébellion de 1878 en NouvelleCalédonie, Nouméa, SEHNC.

LeENHARDT Maurice, 1953 ( $1^{\mathrm{e}}$ éd. 1937). Gens de la Grande Terre, Paris, Gallimard.

Ligue DES DROITS DE L'HOMME EN NOUVELleCalÉdonie, 2003. Bilan de l'accord de Nouméa par la LDH-NC, Communiqué du 4 mars 2003. http://fr.groups.yahoo.com/group/kanaky/message/ 5113

MacLellan Nic, 2005. Conflict and Reconciliation in New Caledonia: Building the Mwâ Kâ, State Society and Governance in Melanesia Discussion Paper, 2005/1, Canberra, RSPAS, ANU.

ManNONi Dominique O., 1950. La psychologie de la colonisation, Paris, Seuil.

Mariotti Jean, 1953. Nouvelle-Calédonie. Le livre du centenaire 1853-1953, Paris, Horizons de France.

-, 2000 (1947). Le dernier voyage du Thétis, Colombani-Savoie Hélène (éd.), Nouméa, Grain de Sable.

MÉlanÉSIA 2000, 1975. Melanesia 2000 : festival des arts mélanésiens, Nouvelle-Calédonie, Nouméa, Festival d'art mélanésien.

Merle Isabelle, 1995. Expériences coloniales: la Nouvelle-Calédonie (1853-1920), Paris, Éditions Belin.

Michel Louise, 1970. La Commune, histoire et souvenirs, tomes I et II, Paris, François Maspero.

MonCELON Léon, 1885 (26 mars). Rapport présenté à M. l'Amiral Peyron, ministre de la Marine et des Colonies, sur les mesures prises et à prendre à la Nouvelle-Calédonie dans l'éventualité d'une nouvelle insurrection des indigènes, par M. Léon Moncelon, délégué de la Nouvelle-Calédonie au Conseil supérieur des Colonies, Aix-en-Provence, CAOM, carton Nouvelle-Calédonie 171.

Muckle Adrian, 2002. Killing the Fantôme Canaque evoking and invoking the possibility of revolt in New Caledonia (1853-1915), Journal of Pacific History 37,1 , pp. $25-44$

-, 2004. Spectres of violence in a colonial context: The wars at Koné, Hienghène and Tipindjé - New Caledonia, 1917, PhD thesis, Canberra, Australian National University.

NAEPELS Michel, 1999. Quelques remarques sur les accords de Nouméa, Journal des anthropologues 76 , pp. 123-127.

Noumea AcCord, 1998. Agreement on New Caledonia, informal translation by the Pacific Community translation services, French Embassy Press and Information Section, http://www.ambafranceau.org/politics/pages/noumea.en.htm. 
Nouvelle-Calédonie et DéPENDANCES, [1879]. Rapport sur les causes de l'insurrection canaque en 1878, in R. Dousset, Colonialisme et contradictions. Étude sur les causes socio-historiques de l'Insurrection de 1878 en Nouvelle-Calédonie, Paris, Mouton, pp. 127-159.

_, 1918. Procès-verbaux du Conseil général, session budgétaire de novembre 1917, Nouméa, Imprimerie nationale.

REPIQUET Jules, 1917. Causes profondes de la rébellion des tribus de la haute Koné et de la Tipindjé, Aixen-Provence, CAOM, carton Affaires politiques 742 .

Rivière Henri-Laurent, 1881. Souvenirs de la Nouvelle-Calédonie ; l'insurrection canaque, Paris, C. Levy (rééd 1980, Papeete, Éditions du Pacifique).

RobIE David, 1989. Blood on their Banner: Nationalist Struggles in the South Pacific, Leichardt (NSw), Pluto Press.

SAussol Alain, 1979. L'Héritage : essai sur le problème foncier mélanésien en Nouvelle-Calédonie, Paris, Société des Océanistes, Publications de la Société des Océanistes 40.

Savore Clovis, 1922. Histoire de la Nouvelle-Calédonie et de ses Dépendances sous les gouverneurs militaires, 1853-1884, Nouméa, Imprimerie nationale.

SEHNC 1978. Causes de la rébellion de 1878. L'avis de Monseigneur Vitte Évêque de Nouvelle Calédonie, Bulletin de la Société d'études historiques de la Nouvelle-Calédonie 35, pp. 1-10.
SÉNÈs Jacqueline, 1987. La terre violente, Paris, Hachette.

Souriau Étienne, 1976. Postface, in DoussetLeenhardt R., Terre natale. Terre d'exil, Paris, Maisonneuve et Larose, pp. 253-255.

TerrIER-Douyère Christiane, 1994. Nous et les autres ou problèmes de mono, bi, pluri-culturalisme en Nouvelle-Calédonie, Être caldoche aujourd'hui, Nouméa, Île de Lumière, pp. 207-222.

TüiBaou Jean-Marie, 1996. La présence kanak, Bensa Alban et Éric Wittersheim (éds), Paris, Éditions Odile Jacob.

Tuibaou Jean-Marie and Philippe Missotte, 1976. Kanaké: Mélanésien de Nouvelle-Calédonie, Papeete, Éditions du Pacifique.

Uregei Hnalaine, 1984. New Caledonia or Republic of Kanaky? Arena 69, pp. 6-13.

Veracini Lorenzo and Adrian Muckle, 2002. Reflections of Indigenous History inside the National Museums of Australia and New Zealand and outside of New Caledonia's Centre Culture Jean-Marie Tjibaou, Electronic Journal of Australian and New Zealand History, http://www.jcu.edu.au/aff/history/ articles/veracini_muckle.htm

Vermast A., [c.1900]. Chez les canaques de la Nouvelle-Calédonie : aventures d'une famille de colons, Gand (Netherlands), I. Vanderpoorten. 